\title{
Going down under full sail. \\ How a labyrinth is wrecked while a murder case remains unsolved. Hans Henny \\ Jahnn's novel Das Holzschiff (1949)
}

\section{Jochen Vogt}

\section{Lieber Gonçalo,}

Dear students, colleagues and friends,

Minhas Senhoras, meus Senhores,

as all of you can imagine, I felt deeply touched when I received the invitation not only to take part in this great symposium to honour Gonçalo Vilas-Boas, but to deliver what they call, even in German nowadays, a "keynote". On reflexion however, I became sceptical, if not a little distressed. Like most other speakers, I presume, I had been asked to focus on one of Gonçalos favourite fields of research. And soon the matter looked like a disaster in disguise. For I was never - to my knowledge - really interested in labyrinths or such mythological themes, and as far as travels are concerned, I have always walked on the practical side. It is true, I travelled quite a deal, mostly with the blessing of Saint Erasmus of Brussels, and often enough, since 1976, to visit friends, colleagues and students at the Universities of Oporto, Coimbra, Lisboa, Aveiro, VilaReal - and even Viseu. And I am still confident I shall make it to Braga one day. But as long as boarding cards are my favourite genre of travel 
literature, I cannot seriously meet the requirements of this symposium.

Many sleepless nights followed. But right in the middle of one, like poor Marcel, many moons ago in Paris, I had a sudden inspiration, got out of my bed, put on my wellingtons, and climbed up to the top attic where twenty-four cardboxes contained more or less useless paperwork from forty years of teaching literature. I was successful with number 17, at the very bottom, finding one of these old fashioned and heavily dusted dissertations. And my mémoire involontaire had been right, I found what I was looking for: not just a neat little labyrinth, but a big one, and mind you: a moving, a travelling labyrinth. That should definitely satisfy the colleagues who had so friendly invited me: Professor John Greenfield and Professor Oliveira, formerly known as my student Teresa, I thought, and hopefully even Professor Vilas-Boas and his distinguished guests. So I stepped down to my first sound sleep in weeks, and my strategy was clear and easy now: As long as selfplagiarism was not yet a crime in the European Union, I would recycle my juvenile speculations in the milder light of old age, and by doing so, hopefully not endanger my doctor's degree.

Getting serious now, and finally approaching my subject, I very much hope you will not regard it as bad manners on my part that I am opening our symposium, in this eminent institute of comparative literary studies, by introducing a German writer. What's more, a German writer completely unknown to the majority of readers in his own country and certainly unknown to all but a very few students of German literature, both there and, I suspect, here. His work has had a minimal impact outside Germany, in part because of the lack of translations.

Hanns Henny Jahnn was born in Hamburg in 1894: that makes him one year younger than Kafka and five years older than Brecht, two writers with a world-wide reputation and writers to whom Jahnn felt close and with whom he felt himself an equal. (It's harder to be positive about his relationship to the third of the world-ranking German authors of the last century, but Jahnn's life-long obsession with Thomas Mann combined jealousy of Mann's success with the contempt which Jahnn felt for the 'slick' narrative technique of this colleague and competitor .) 
Jahnn's own career as a writer was marked far more by disappointments and scandals than by successes. He won the prestigious Kleist Prize in 1920, at the age of twenty-six, on the basis of one blood-thirsty family drama, which is usually seen as part of late Expressionism, but would have been no less at home in the age of Shakespeare and Marlowe. Critics and public alike agreed in finding the themes of his plays disgusting nothing but violence, endless varieties of sexual excess, death and piles of rotting flesh. Jahnn was never less than controversial: his biting attacks on modernity, on technical and bureaucratic rationalization, on the destruction of the environment, on nationalism and militarism, not forgetting his polemics against the churches for what they were doing to Christianity. He remained controversial up to his death in 1959 through his campaign - in a sort of entente cordiale with Brecht - against nuclear armament in Germany and Europe. The fact that his ideas, interests and activities extended far beyond literature did not help him construct a literary career like Thomas Mann's. As a conscientious objector he escaped to Norway with his friend Harms as early as the summer of 1915 - and Norway's mountains form a monumental setting for Jahnn's later novels. He experimented in the 1920s with the foundation of a religious community, called Ugrino, based on a kind of paganism, and planned monumental public building works to provoke social re-thinking. He produced elaborate and professional editions of ancient music, especially of Samuel Scheidt and Dietrich Buxtehude, composers of the 17th century. As an organ-builder and expert Jahnn enjoyed respect, building organs for churches in Hamburg-Langenhorn, or in Stavanger, Norway, and for the central radio station in East Berlin, the "Deutschlandsender". But all things considered, there were too few commissions for a steady income. In the 1930s and 40 s, Jahnn spent much time and too much money on ecological farming projects, horsebreeding, dabbling in hormone research and so, not surprisingly, he tottered most of his life on the brink of financial ruin (see Freeman 1986, passim).

It is to be expected that a man like Jahnn, who never fitted in with any literary or political programme, would fail to find a place in the literary scene of either the Weimar or the Federal Republic, quite apart from the financial and creative problems which exile brought with it (see Vogt 1992, passim). At least his outsider status has meant that every 
ten or twenty years a new generation of admirers has come forward to campaign for Jahnn and to assure him the recognition and fame which they - and, as a matter of fact, Jahnn himself - were convinced he deserved. These admirers were sometimes young writers, or critics and journalists, sometimes academics and sometimes 'common readers'. One of his first admirers was Klaus Mann, who saw in Jahnn perhaps the father he wished he had had. - I myself was, in all modesty, part of such a group in the late 1960s, but I would like to focus on voices from the $1950 \mathrm{~s}$, for they start to introduce the comparative element into our discussion.

A young critic from Stockholm who probably felt drawn to Jahnn because of his exile in Scandinavia, claimed in 1954 that Jahnn's major works were "the German equivalent to James Joyce's Ulysses". I'm talking here, of course, of the then unknown painter and filmmaker, in later years the celebrated novelist and playwright Peter Weiss, who had had to leave Germany in 1933. - And the well-established Austrian poet Ingeborg Bachmann, in her Frankfurt poetry lectures of 1959, placed Jahnn "between Marcel Proust and Samuel Beckett' on account of his radical 'analysis of the self' (cf. Vogt 1992, p. 287sq.) Twenty-five years later Uwe Schweikert - to whom we owe an outstanding edition of Jahnn's work reinforced these comparisons when he wrote:

Hans Henny Jahnn remains the least known of the great German authors of the first half of the twentieth century. The powerful language of Perrudja and the trilogy Fluß ohne Ufer with its dynamic visionary quality are the German pendants to the novels of Proust, Joyce and Faulkner. (cf. Jahnn, 1984, cover)

These are not empty comparisons. In 1940, when he was living under the most difficult of conditions as a farmer on the island of Bornholm in occupied Denmark, Jahnn sent a note to his publisher in Leipzig begging for books by Proust, Bernanos, Kafka and Faulkner. I wish to return to the intertextual network of themes and styles in a few minutes, but for the moment I wish to go back to Hamburg, more precisely to Stellingen near the harbour, where Jahnn was born. His father was a ship's carpenter, and the atmosphere of ship-building and the sea, together with their metaphors, is the sustaining force in the short novel Das Holzschiff (The Wooden Ship), which Jahnn wrote on Bornholm in the 1930s but 
could not publish until 1949 in Munich. One or two quotations will give you a sense of the text; and this is the first paragraph:

Suddenly, as if it had emerged from a bank of mist, the fine ship became visible. Its bow was a yellow-brown, its lines emphasized by the lines of black pitch; its three masts in perfect alignment, the sweep of its spars, the intricate patterns of the rigging and the shrouds. The red sails were furled, lashed to the yards. Two small steam-tugs, one forrard and one astern, edged it to the wharfside. A proper three-masted barque, a few thousand square feet of sail. Old Lionel Escott Macfie Esquire from Hebburn on Tyne had built it from teak and oak. The man was strange, a throw-back to other centuries, but a genius in curves. (Jahnn 1986, vol. 1, 7)

Subsequently the reader is brought aboard. Gustav, the young man engaged to Ellena, who travels with her father, the ship's captain, is the central character of this novel and its sequel. He explains to the captain how he had intended to travel as a stowaway and how he had failed to find anywhere to hide:

We were standing in a broad passage-way which ran across the ship, from one side to the other. We could see nothing stored in the passage-way, just the beams and planks of the ship's frame. It seemed no more than a wasted space, with no purpose at all. At first we thought we could go no further, but as we went along the passage-way we found a hole in the floor, very close to the ship's side. We went through and down some steps, deeper into the ship's interior, until we found ourselves in a space like the one above, only smaller, as the curve of the ship's side cut into the width. Two doors led forward and astern into further dark spaces. We did not try to go through, but were drawn to the further end of the passage-way, where once again there was an opening and steps going down deeper, at a strange angle. I felt we had reached the very bottom of the ship, immediately above the keel. The wood surrounding us on all sides was massive, and we could not make out the shape of the space we had got into. I couldn't describe it to you even now. We could hardly stand up, but there was plenty of space, huge wooden bulkheads rising up at strange angles, bilge tanks and blocks of metal dispersed on planks across the bottom. We could see the ribs of 
the ship narrowing towards the stern, like the skeleton of a gigantic whale. "Yes," said the captain, "for an outsider the interior of a ship is a very mysterious sight." (ibid., 31sq.)

The deliberate precision of the description gives an oppressive sense of disorientation, and this feeling gets stronger as the story progresses, until it becomes the essence of the whole 'labyrinthine experience'. It's the product of a hyper-realist technique, which can at any moment switch over into confusion and claustrophobia. These are familiar effects in the visual arts, from Piranesi to Escher. Looked at from another point of view, we could see the technique as one of those moments at which technical rationality becomes mythical compulsion. You'll recall that Theodor Adorno and Max Horkheimer, a few years later in their American exile, built such moments into the central argument of The Dialectic of Enlightenment.

For the moment we will stay with Gustav, who finally is allowed to travel as a passenger on this ship, but becomes desperate with anxiety when, shortly after setting sail, his fiancée vanishes without trace. Has she fallen overboard, or is she hiding somewhere in the ship, a prisoner, or a corpse? Gustav and Ellena's father - with the help of the ship's carpenter, Klemens Fitte, and Able Seaman Alfred Tutein - begin a systematic, but increasingly panicky search for the missing girl. As they search, they discover more and more levels in the labyrinth, dead ends, locked rooms and doors, a mysterious cargo stored in sealed crates, and a whole series of constructions, whose purpose and function remain obscure.

As their anxiety grows, a general aggression comes out, gradually spreading to the whole crew, an aggression laced with massive sexual fantasies, which eventually break out in pure violence. When the carpenter Fitte, a Herculanean figure, takes his axe to the last of the closed rooms, he smashes the keel wall and destroys the ship. In one of the last scenes of the novel the ship's sinking is described in slow-motion-technique through the eyes of those who were rescued, among them Gustav and Tutein:

Gustav's eyes were drawn to the ship as it sank. It was in the grip of inconceivably powerful forces which were now pulling it below the waves. The final struggle between staying afloat and sinking was only slowly being resolved. It was a solemn moment. 
Destruction did not seem in a hurry to reach the decisive moment. As the minutes slowly passed, the ship's stern got sucked in deeper, and the bow rose up higher. The corroded green of the copper plates under the waterline became more and more visible, just as a dying fish shows its ivory belly. The movement had an extraordinary, unearthly tension. These were the last moments of a dying forest, as the proud construction of old Lionel Escott Macfie was gradually undone. Ellena's fiancé had lost all power over himself. In this extreme moment he was waiting for something that might justify the destruction which he had wrought - he was waiting for a door to fly open, for the ships owner to stride out, and for Ellena to be in his arms again. At the very last moment, he was hoping that her death would be revoked.

Then the bows reached the water. Only the bowsprit was left sticking out. A line of white foam was left on the surface. The air still echoed with the noise of the sails flapping against the swell. The figurehead was left, poised for no more than a minute vertically above the water, facing the lifeboats. All eyes turned to it, although no-one could remember having seen it before. It shone as if made of yellow marble. A woman. The statue of a goddess, shimmering and coarse-skinned. Her arms reached behind her into the brown, sea-beaten wood, her strong thighs grasped the trunk of the keel. A powerful, seductive song reached across the waters to the men, the shameless promise of her swelling breasts. And then the apparition had vanished (idem: 216).

It's almost a cliché to understand this ship as a labyrinth. We ought to call it a moving, indeed a travelling labyrinth - heading to its own destruction like many literary ships, boats and rafts before - from Homer and Dante to Rimbaud and Brecht. But we can go even further and call not only the wooden ship in the novel, but the novel itself a labyrinth - to do this we need to look beyond the spacial relationships in the novel and to consider its narrative structures, that is created primarily by its use of time. We can call The Wooden Ship a four-dimensional labyrinth, for the spacial mystification we examined is heightened by its temporal structure, which is based on the simple device of ellipsis. As readers we mostly stay close to the protagonist and experience with him the shifts in his sense of time - this a basic narrative device of high modernist fiction. But the secrets of the 
plot and in particular the mystery of the murder are concealed from his as well as from our eyes. What the philosopher Ernst Bloch remarked of the detective novel - that it announces its arrival with a corpse ("der Detektivroman fällt mit der Leiche ins Haus") - is not quite true of Jahnn's novel. Here the corpse is hidden in a blind spot, perhaps in a closed room, but definitely in a narrative black hole.

By now, as my friends will have suspected for some time, I'm heading for a hidden theory. Actually, it's fairly obvious that Jahnn's novel is built round one of the central features of the crime novel, or to be more precise, of the detective story in its classic form. The isolated, but labyrinthine room in which something dreadful happens and the piece of time excluded from the narration in which that event took place - these are, as Kant, the philosopher would have said, the transcendental conditions for the detective story, the genre which consists solely in the reconstruction of events in that closed-off labyrinth - a reconstruction which leads necessarily to the identification of the murderer.

We're all familiar with this, from Poe's Murders in the Rue Morgue to Agatha Christie, who liked sending her labyrinths off on a journey, down the Nile, on the ten to five from Paddington, over the clouds, or on the Orient Express - and finally to John Dickson Carr, also known as Carter Dickson, the real virtuoso of the closed room detective story.

Jahnn's novel certainly does not follow these intentions. That's most obvious at the end, as the ship - which got its name Lăs from a courtesan in classical Greece - sinks and the murder, if there ever was one, remains unresolved. There's no victim, there's not really a case at all, and certainly no murderer. The fact that the he indeed is sitting next to Gustav in the life-boat, and that he confesses his crime to him after both of them are safe, - this is something we don't discover until the first chapter of Jahnn's next novel, Die Niederschrift des Gustav Anias Horn nachdem er neunundvierzig Jahre alt geworden war (Gustav Anias Horn's memorandum, written when he has become forty-nine years of age). One might say this was a real cliffhanger, though Jahnn would not have understood the word. And of course he is trying to create something other than tension. The case of Ellena - itself a name resonant in mythology - isn't solved in the novel itself: the first rule of detective fiction is negated, perhaps even invalidated. 
Certainly, Jahnn was not trying to write a conventional detective story, or to move into the genre, although he did remark in a lecture in 1954: 'The fact that we writers are permanently in a state of financial ruin means that all of us are desperately hoping that an idea for a good detective story will occur to us.' (see Vogt 1970, 15, cf. 15-56) But he wasn't really talking of anything more than that the housekeeping money had run short, much like his younger Swiss colleague Friedrich Dürrenmatt, who settled on the same strategy, but more systematically and with rather greater success. As a matter of fact, two of Dürrenmatt's most popular crime novels - subsequently used to torture hundreds of thousands of German and Swiss students in their school-leaving exams - certainly did not just 'occur to him'. He simply stole the story lines from Georges Simenon: a case of plagiarism on a high artistic level.

But there is an important parallel between The Wooden Ship and these two stories, The Judge and his Hangman and The Pledge from 1952 and 1959 respectively. Both writers, by deconstructing the conventional rationally and logically conducted solving of a crime, throw into question not only the genre rules of the detective story but the fundamental basis of modern law and society. Coincidence challenges reason as the principal actor. We may perhaps agree that Dürrenmatt, by showing contingency to eliminate reason and logic in specific cases, still remains within the framework of modern thought, perhaps through his affinities with Existentialism. Jahnn however makes his themes out of shipwrecks and every kind of catastrophe, out of individual and universal conflicts of every kind, and he does so by conjuring up the timeless and primeval forces of human existence, of nature and of the universe. Life and death, birth and mortality, human and animal, man and woman, instinct and reason, nature and technology, war and peace, crime and punishment, pride and prejudice, joy and pain, fate and chance - to name but a few. In doing this Jahnn goes way back far before the modern period: Hanns Wolffheim rightly agrees with Walter Muschg, a German and a Swiss scholar among Jahnn's early admirers, in calling Jahnn 'the tragedian of creation'.

With The Wooden Ship Jahnn used the structures of the detective novel in the service of his tragic world-view, by making two substantial changes to it. First: the case is not 
solved. In this respect, Jahnn is about twenty or thirty years ahead of his time in the theory and practice of the detective story: French writers Boileau and Narcejac formulated the clear requirement that 'the crime novel should not mark the triumph of logic, but celebrate the bankruptcy of thought' in 1966. Jahnn's second innovation concerns the relationship between form and narrative technique. It was long true of the detective novel that it dealt with the settings and problems of social modernity using conventional, pre-modern narrative techniques. Modernity without modernism. The crime novel was extremely slow to modernize its narrative tools - "stream of consciousness" would be one example of a technique all but unknown to the classical detective story. Jahnn on the other hand although he doesn't ignore themes and problems of the modern world - relates those issues to timeless archetypes, but he does so - at least in this trilogy of novels called Fluß ohne Ufer (River without Banks) - by means of advanced modernist techniques. In short, he uses modernism against modernity.

In the final section of my paper I wish to shortly discuss Jahnn's debt to some major authors of literary modernism - debts which Jahnn sometimes denied and sometimes acknowledged. In order to discuss this I need to go one step back from The Wooden Ship and to consider Jahnn's first novel, Perrudja. Based on Jahnn's experience in Norway, this is an utopian novel, attempting to resolve the tensions between mankind, nature and technology. Jahnn reworked the manuscript of his novel in 1927, after having closely studied Joyce's Ulysses, which had just been translated into German. He put into his novel his own version of stream of consciousness and scattered phrases from Joyce as leitmotifs throughout his text. (His fellow writer Alfred Döblin was similarly engaged at the same time, adapting his Berlin Alexanderplatz novel in a similar way. Both novels appeared in 1929 - plagiarism or intertextuality? Who knows.) In any case, this avantgarde writing tends towards a freeing of language, combined with its semantic intensification.

In The Wooden Ship, as you will have observed, Jahnn goes back on his own experiment and refers to the novel as a traditional novella. That's a characteristic feature of German exile writing in general, including Brecht's, but it's clear as well that Jahnn was little able to appreciate the ironic and parodistic effects which abound in Joyce's work. He started 
reading other texts and saw The Wooden Ship in a new light. 'I can't deny a slight affinity with Kafka', Jahnn wrote, 'but my work is much closer to reality, with hard sentences in touch with the physical world'. (cf. Vogt 2004, 66) Certainly, Jahnn was not wrong about this affinity, especially if we consider how important mystification is to Kafka's work - a technique which Jahnn used to good effect in his short novel.

After its appearance in 1949, German critics tended to compare Jahnn with Conrad or Melville, but such comparisons went no further than the atmospheric writing about the sea. I can see no specific intertextual reference to either of these authors, although the whole theme of the sea and shipwrecks opens up a wide field, or better: an ocean of associations in literary history and the other arts, from Noah's Ark to the sinking of the Titanic. Without ourselves drowning in examples, we can agree that a sea journey is one of the richest sources of images in our culture - as Portuguese history and national literature properly reminds us.

Getting back to terra firma, the sequel to The Wooden Ship sees Gustav and Tutein, having survived the wreck, transported to Norway, where they live out their life partnership, their bond of friendship and love, with no smaller ambition than to overcome what the philosopher Schopenhauer calls 'individuation' - a condition which his most famous fictional reader, Thomas Buddenbrook, experiences as the prison and dungeon of his own self. The attempt to merge two individuals is doomed to fail. Following Tutein's early death, Gustav struggles for twenty years to express his tragic view of life in musical laments in the grand manner. He describes all these events just before his own death, in the fifteen hundred pages of the Memorandum - a cross between a memoir and a diary. A firstperson narrative tells of his life since the shipwreck. It is interspersed with present-tense accounts of his artistic struggles. The text goes on to its violent conclusion. A confidence trickster has ingratiated himself into Gustav Horn's life, and this man kills him. The diary breaks off in the middle of a sentence, so this novel too ends with a murder.

Leaving aside the themes of eros and sexuality, and of mankind's relation to nature and technology, we can identify two important thematic and structural features which link Jahnn to major fellow writers. 
First. The Memorandum of Gustav Anias Horn is a book about a musician; it deals with Horn's life-long attempts as a composer to find new forms of expression for new types of experience, some of these extreme. The most famous tradition of European music is of no help to him, indeed he tries to ignore the whole classical and romantic tradition, and to fuse together Renaissance and Baroque music with the music of the early twentieth century. The crucial elements are polyphony and serial composition. I've said enough to make clear that Jahnn's novel is in its content extremely close to, indeed in direct competition with Thomas Mann's music novel, Doktor Faustus, which had appeared two years before the Memorandum, in 1947. There are striking parallels between the actual works which the two fictional composers, Horn and Leverkühn, write. But there is definitely no question of one novelist influencing the other: Jahnn's manuscript was completed by 1942 and - to be frank - Thomas Mann was probably not even aware of Jahnn's existence. Nevertheless, these parallels have provoked a prolonged interest among researchers.

Secondly. The Memorandum is a novel of memory. Memory is the central aspect of the story, but we wonder if it is strong enough to sustain the entire plot. In 1943, a year after he had completed the novel, Jahnn wrote to Gustav Gründgens, then theatre director in Berlin and a favourite of Goebbels: 'I have often thought in the past that one could see a parallel to Proust's novel, but just now that seems absurd - its intellectual roots are with Kafka, and only with Kafka.' (cf. Vogt 2004, 66) Of course, Jahnn will have found the social and cultural setting of Proust's novel, together with the whole fin de siècle decadence very alien. And even the theme of homosexuality, common to both novels, is treated in diametrically opposed ways by the two authors. But Proust's novel and Jahnn's Memorandum both use the constructive power of memory in the aesthetic ordering of their material, and their subject is the same: a life which has passed and is now lost. It's fifty years ago now that, with the cheekiness of youth, I made such a claim for the books, and in the meantime critics have hardened up Jahnn's links to Proust. I offer one single example, from a locus classicus of world literature. Proust and Jahnn focus strongly on the shortcomings of intentional memory. In $\grave{A}$ la Recherche intentional memory is filled out at that magical moment when Marcel dips his madeleine into his lime-flower tea and mémoire 
involontaire is set free. Jahnn's example for the same experience is the smell of birch bark in a Norwegian hut. 'Despite the lateness of the hour', Gustav Horn records at a very early point in his memorandum,

I decided to light a fire in the stove. The white birchwood logs, dry and brittle, smelt of resinous growth, of soil and cool leaves [...] The scent from the flame - it's been familiar to me for years, like the page of a book one reads over and over again - awakens memories, conjures up a whole country, its mountains and rivers, its animals, its people and its trolls: Norway. Kristi from Urrland taught me how to use birch bark to light a fire. As I looked at the bark I saw its markings as bars of music. I heaped up a small pyre of chippings over the dark flames. (Jahnn 1986, vol. 2, 235)

On this moment the entire temporal and spacial structure of his powerful novel is built, just as is the case of Proust's madeleine. Perhaps Jahnn lost confidence in the power of involuntary memory to structure his novel à l'intérieur, and for that reason tried to stabilize the novel with a kind of exterior framework. And that prop he finds in another French writer, one whom he clearly rated more highly than a decadent socialite like Marcel Proust. Georges Bernanos' Journal d'un curé de campagne stands in Jahnn's library and he took over the arrangement of the chapters and further features into his novel. I would like to add that my colleague and former student, Marion Bönnighausen, discovered this link in her work on Jahnn's Memorandum and Doktor Faustus (cf. Bönnighausen 1997). For myself I hope I've made clear that - despite his troubled life and notwithstanding his somewhat eccentric view of the world - Hans Henny Jahnn is firmly rooted in European modernism, and not only therefore should be mentioned in the context of our comparativist symposium.

For my old friend and colleague Gonçalo Vilas-Boas, in spite of all those security checks before, during and after my flight, I have brought a very nice recent edition of Das Holzschiff to inspire his first reading. For others who are eager now to read River without Banks, merely two thousand and one hundred pages (!), I can give no better recommendation than the words Jahnn himself wrote in in celebration of Ulysses. 'What matters here', Jahnn wrote, 
is that form and the need for variation - the absolute bed-rock of literary creation - can be observed in this work, it can be smelt and tasted here. For the first time the reader has a measuring-rod to show us that the feelings of traditional literature have betrayed us [...]. Buy the book for yourself and read it over and over again. And if it frightens you, ask yourself if your life is not built on blindness, deafness and lies. (Jahnn 1930)

\section{Works Cited}

Bönnighausen, Marion (1997): Musik als Utopie. Zum philosophisch-ästhetischen Kontext von Hans Henny Jahnns „Die Niederschrift des Gustav Anias Horn“ und Thomas Manns „Doktor Faustus", Opladen, Westdeutscher Verlag.

Das Hans Henny Jahnn Lesebuch (1984), ed. Uwe Schweikert, Hamburg, Hoffmann und Campe.

Freeman, Thomas (1986): Hans Henny Jahnn. Eine Biographie, Hamburg, Hoffmann und Campe.

Jahnn, Hans Henny (1930): „James Joyce: Ulysses“ [Rezension], Der Kreis. Zeitschrift für künstlerische Kultur, vol. 7, S. 473.

-- (1986): Fluß ohne Ufer. Roman in drei Teilen. 3 vls., [Werke in Einzelbänden. Hamburger Ausgabe. Ed. Uwe Schweikert], Hamburg, Hoffmann und Campe.

Vogt, Jochen (1970): Struktur und Kontinuum. Über Zeit, Erinnerung und Identität in Hanns Henny Jahnns Romantrilogie „Fluß ohne Ufer“, München, W. Fink.

-- (1992): „Der Ruhm ist die Summe aller Missverständnisse. Facetten zur 
Rezeptionsgeschichte Hans Henny Jahnns in der Bundesrepublik“, in: Dieter Sevin (ed.): Die Resonanz des Exils. Gelungene und misslungene Rezeption deutschsprachiger Exillautoren, Amsterdam, Rodopi, pp. 286-298.

-- (2004): „Kafka, Proust, Joyce oder ...? Was Hans Henny Jahnn von sich und den Kollegen hielt“, in: J. V.: Knapp vorbei. Zur Literatur des letzten Jahrhunderts, München, W. Fink, 57-72. 